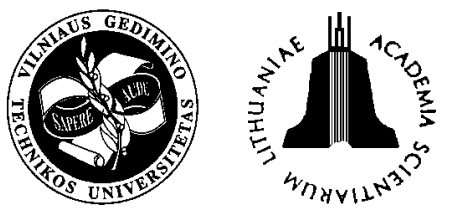

\title{
LABORATORY INVESTIGATION OF TYRE SLIDING GRIP COEFFICIENT
}

\author{
Rosen Ivanov, Rusi Rusev, Plamen Ilchev \\ Dept of Automobiles, Tractors and Fork-Lift Trucks, University of Rousse, \\ Studentska str.8, 7017 Rousse, Bulgaria.E-mail: rossen@ru.acad.bg; rgr@ru.acad.bg
}

Received 11 January 2006, accepted 9 May 2006

\begin{abstract}
The paper presents the results of a laboratory investigation on the variation of the tyre sliding grip coefficient depending on the tyre construction, the air pressure, the vertical load and the wheel camber. Eight different models of tyres are tested. A significant reduction of the tyre sliding grip coefficient on a hard ground was registered, when the tyre pressure is low and the wheel camber is bigger. The analysis of results and explanation of causes are done.
\end{abstract}

Keywords: grip, grip coefficient, tyre performance.

\section{Introduction}

The influence of air pressure in the tyre $p$ and vertical load $G_{k}$ on the tyre sliding grip coefficient $\varphi$ has been investigated in many works [1-20]. In some of the articles $[2,4,13,14,20]$ it is established that on a hard road, the wheel camber $\alpha$ changes the value of coefficient $\varphi$.

The data for the influence of the constructive properties of the tyre on the relationship between $\varphi$, $G_{k}$ and $p$ were collected $[2,4,15,19]$. However, this influence has not been thoroughly clarified.

In the University of Rousse, Department of Automobiles, Tractors and Fork-Lift Trucks, work on problems of pneumatic tyre grip has been done for years. Experimental data on different types and constructions of the tyre are collected. The results show that tyre sliding grip coefficient and its variation depend on the tyre load, the air pressure in the tyre and the wheel camber.

An experimental facility for pneumatic tyres test was created [21]. It allows to test not only car tyres but also tyres of lorries and busses, and it can be used as a laboratory (Fig $1 \mathrm{a}$ ) and as a mobile (Fig $1 \mathrm{~b}$ ) variant.

In this article the influence of the vertical load, the tyre pressure and the wheel camber on the sliding grip coefficient of the tyre is investigated. The results concern a dry horizontal road and were obtained for different constructions of tyres with different wear.

\section{Influence of the vertical load and the air pressure in the tyre}

The experiments were carried out at three values of tyre pressure - 0,25 $\mathrm{MPa} ; 0,20 \mathrm{MPa} ; 0,15 \mathrm{MPa}$. The vertical load on the tyre $G_{k}$ was changed in the limits from 1,5 to $4,0 \mathrm{kN}$ (to $5,5 \mathrm{kN}$ for some of the tyres) by on step of $0,5 \mathrm{kN}$. The load, longitudinal and lateral forces in the contact patch between the tyre and the road surface were measured by dynamometers with an accuracy of $0,02 \mathrm{kN}$. The grip force was measured in case of $100 \%$ slip between the tyre and the road surface, and minimum speed of the slip.

These series of experiments were done when the tyre was without the wheel camber. All experiments were repeated three times. The road surface of platform 8 was dry concrete.

The forces and the sliding grip coefficients in pure longitudinal and lateral directions were determined. For this goal, the values of air pressure in the tyre and vertical load were established, and then the platform was moved in longitudinal or lateral direction, and a full slip between the tyre and the road surface was realized. The values of grip forces in longitudinal $F_{x}$ and lateral $F_{y}$ directions were obtained. The sliding grip coefficients of the tyre in longitudinal $\varphi_{x}$ and lateral $\varphi_{y}$ directions were calculated by expressions:

$$
\varphi_{x}=\frac{F_{x}}{G_{k}}, \quad \varphi_{y}=\frac{F_{y}}{G_{k}},
$$

where $G_{k}$ is the vertical load on the wheel, $\mathrm{kN}$; $p$-the air pressure in the tyre (inflation pressure), $\mathrm{MPa}$; 
$F_{x}, F_{y}$ - the tyre grip forces in lateral and longitudinal directions, $\mathrm{kN} ; \alpha$ - the wheel camber, deg; $\varphi$ - the tyre sliding grip coefficient (grip coefficient at $100 \%$ slide or side slip); $\varphi_{x}, \varphi_{y}$ - the tyre sliding grip coefficients in lateral and longitudinal directions.

In this comparative investigation 8 tyres of different construction, dimensions, and wear of the tyre tread were tested. The main technical data of the tyres are given in Table and the pictures of 6 of them are given in Fig 2. The results of sliding grip coefficients in case of $100 \%$ slip in longitudinal or lateral directions, at different values of tyre pressure and vertical load are presented in Fig 3 and 4.

The obtained results for all models show a decrease of the sliding grip coefficients in two directions when the vertical load increases and air pressure in the tyre decreases in case of the slip on the hard road surface.
The decrease of the sliding grip coefficient when the vertical load increases is caused by the increase of tangential stress in the contact patch $[4,19,20]$. When the contact patch forms on the elements of tyre tread, which are included in contact area, the tangential stresses arise. The experimentally obtained tyre footprints of contact patch show that for a part of the tread elements tangential stress exceeds the limit of the grip and these elements slip. When the vertical load is bigger and the tyre pressure is lower, the zone, in which the tread elements slip, becomes larger.

Usually for the tyres of bigger width, the sliding grip coefficient in the lateral direction $\varphi_{y}$ has a bigger value than this one in the longitudinal direction $\varphi_{x}$ at all three values of the tyre pressure. For other tyres, in some other works and in previous articles of the authors $[2-4,6,9,20]$ the opposite result was ascertained -
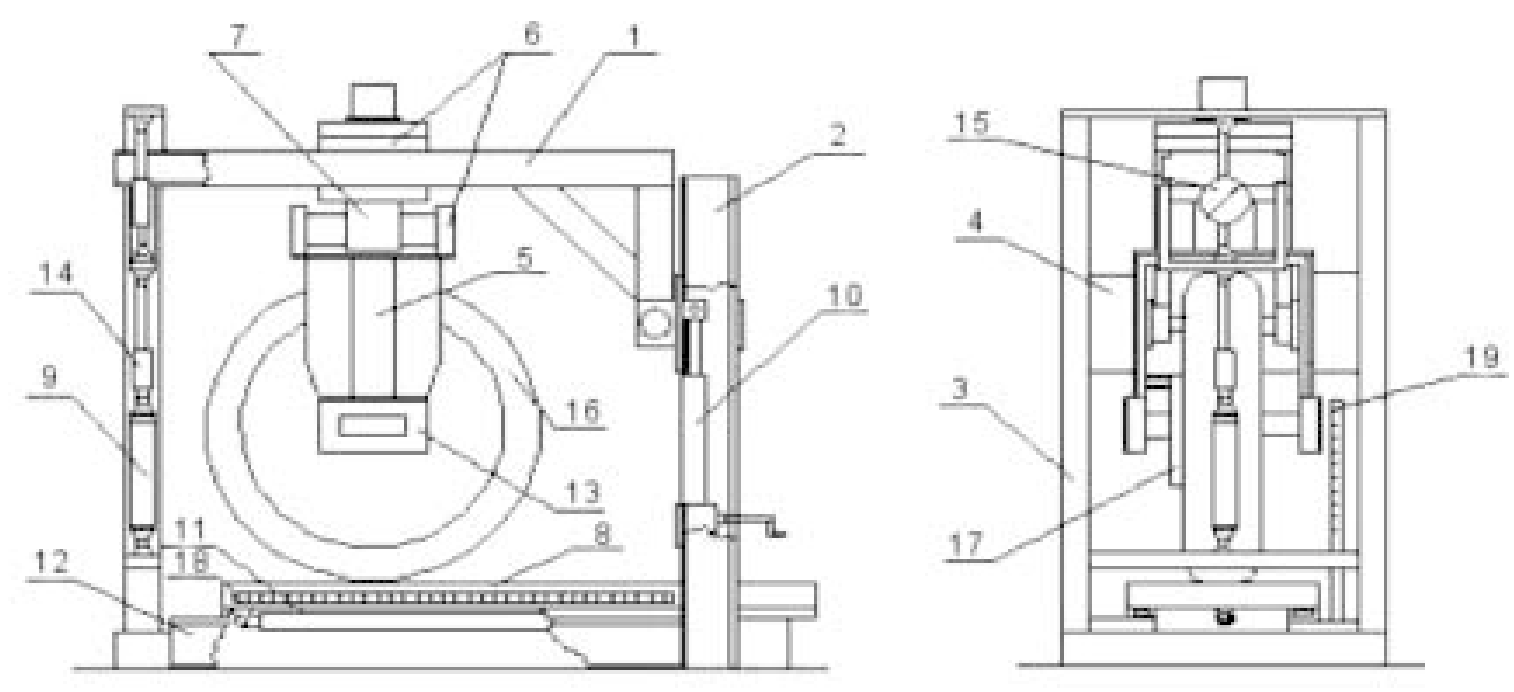

a)

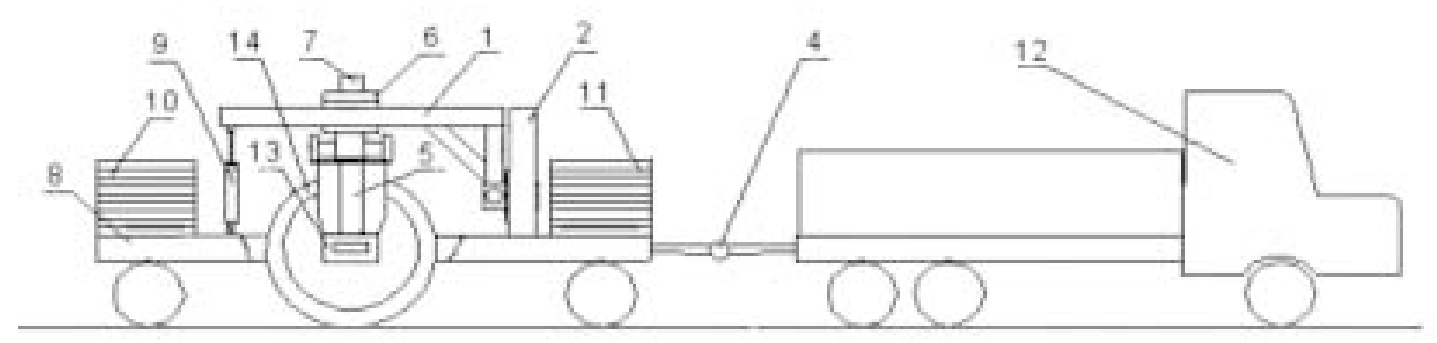

b)

Fig 1. Laboratory (a) and mobile (b) variants of the tyre test facility :

a - laboratory variant: 1 - loading frame ; 2 - vertical columns ; 3 - vertical frame; 4 - holding plate; 5 - fork; 6 - bearings; 7 - pivot-shaft; 8 - road surface platform; 9,11 - hydraulic cylinders; 10 - mechanical gig; 12 - fundament ; 13 - measurement assembly; 14 - extension; 15 - dynamometer; 16 - tested tyre ; 17 - brake; 18, 19 - 1 inear scales; $b$ - mobile variant: 4 - draw-bar ; 8 - trailer; 10,11 - trailer load; 12 - tractor 
The main technical data of the tested tyres

\begin{tabular}{|c|c|c|c|c|c|c|c|}
\hline Tyre model & $\begin{array}{l}\text { Manufact } \\
\text { ured in }\end{array}$ & Tread & $\begin{array}{c}\text { Wear, } \\
\%\end{array}$ & $\begin{array}{l}\text { Maximum } \\
\text { load, kg }\end{array}$ & $\begin{array}{c}\text { Maximum } \\
\text { air } \\
\text { pressure, } \\
\text { MPa }\end{array}$ & Tyre type & Carcass \\
\hline $\begin{array}{l}\text { Skyway } \\
6,5 "-134 \mathrm{PR}\end{array}$ & China & summer & 50 & 420 & 0,36 & $\begin{array}{l}\text { bias-ply, } \\
\text { tube, }\end{array}$ & $4 \mathrm{~N}$ \\
\hline $\begin{array}{l}\text { Stomil } \\
\text { 165/80 SR } 134 \mathrm{PR}\end{array}$ & Poland & $\begin{array}{c}\text { universal, } \\
\text { asymmetric }\end{array}$ & 10 & 465 & 0,36 & $\begin{array}{l}\text { radial, } \\
\text { tube }\end{array}$ & $2 \mathrm{Pe}+2 \mathrm{~N}$ \\
\hline $\begin{array}{l}\text { Belshina } \\
\text { 175/70 R13 82H }\end{array}$ & Belarus & $\begin{array}{c}\text { winter, } \\
\text { asymmetric }\end{array}$ & 0 & 465 & 0,36 & $\begin{array}{l}\text { radial, } \\
\text { tubeless }\end{array}$ & $1 \mathrm{~N}+2 \mathrm{St}+2 \mathrm{~N}$ \\
\hline $\begin{array}{l}\text { Goodyear } \\
\text { 175/70 SR } 13 \text { 4PR }\end{array}$ & UK & $\begin{array}{l}\text { universal, } \\
\text { summer, } \\
\text { asymmetric }\end{array}$ & 75 & 465 & 0,36 & $\begin{array}{l}\text { radial, } \\
\text { tubeless }\end{array}$ & $1 \mathrm{Pe}+2 \mathrm{St}+1 \mathrm{~N}$ \\
\hline $\begin{array}{l}\text { Semperit } \\
\text { 185/60 R14 82T }\end{array}$ & Austria & $\begin{array}{c}\text { summer, } \\
\text { symmetric, } \\
\text { with direction }\end{array}$ & 80 & 475 & 0,30 & $\begin{array}{l}\text { radial, } \\
\text { tubeless }\end{array}$ & $1 \mathrm{R}+2 \mathrm{St}+1 \mathrm{~N}$ \\
\hline $\begin{array}{l}\text { Nokian } \\
\text { 205/65 R15 95H }\end{array}$ & Finland & $\begin{array}{l}\text { symmetric, } \\
\text { with central } \\
\text { longitudinal } \\
\text { groove and } \\
\text { direction }\end{array}$ & 75 & 670 & 0,30 & $\begin{array}{l}\text { radial, } \\
\text { tubeless }\end{array}$ & $1 \mathrm{~N}+2 \mathrm{St}+2 \mathrm{R}$ \\
\hline $\begin{array}{l}\text { Viking } \\
\text { 205/50 R15 86V }\end{array}$ & UK & $\begin{array}{l}\text { symmetric, } \\
\text { with } 3 \text { central } \\
\text { longitudinal } \\
\text { grooves and } \\
\text { direction }\end{array}$ & 50 & 530 & 0,30 & $\begin{array}{l}\text { radial, } \\
\text { tubeless }\end{array}$ & $1 \mathrm{Pe}+2 \mathrm{St}+2 \mathrm{~N}$ \\
\hline $\begin{array}{l}\text { Vidlon } \\
6,5 "-16 \\
\text { (for agricultural } \\
\text { tractor) }\end{array}$ & Bulgaria & $\begin{array}{l}\text { universal, } \\
\text { winter }\end{array}$ & 0 & 560 & 0,33 & $\begin{array}{l}\text { bias-ply, } \\
\text { tube }\end{array}$ & $4 \mathrm{~N}$ \\
\hline
\end{tabular}

N - NYLON, St - Steel, R - RAYON, Pe - POLYESTER

bigger values of sliding grip coefficient in longitudinal direction. This correlation is typical of old model biasply tyres with less width of the profile.

The correlation between the values of coefficients in two directions depends on the form of contact patch and grooves of the tread. For example, the footprint of the tyre Belshina 175/70 R13 82H (Fig 5) has a larger width than length at small and medium values of load. At bigger values of vertical load the dimensions of contact patch in the two directions are approximately equal. This form of the contact patch and the presence of 4 longitudinal grooves in tread are the cause of bigger value of sliding grip coefficient in lateral direction, obtained at all three values of air pressure in the tyre.

The zone of variation of sliding grip coefficient in lateral direction is wider than this one for coefficient in longitudinal direction (Fig 3 and 4). In general, the obtained zones fit with those given by other authors [7].

The curves for different tyres have a similar character (Fig 3 and 4) and in all of them there is a specific zone. In this zone the influence of load variation on the values of sliding grip coefficients is very small, because of significant change of form and area of contact patch at this load. The results can not be described with a general model, because the specific zones of different tyres have a different width and position.

A successful modeling of the results (Fig 3 and 4) was worked out by the authors, only using Neural Network tool of MATLAB [22].

\section{Influence of the wheel camber and the tyre construction}

In real road conditions the wheel rolls at presence of a wheel camber angle $\alpha$. This angle is changed significantly when the wheel is turned by steering, and its change depends on values of the king-pin camber and the caster angle.

As an illustration of influence of the wheel camber, the results of two passenger car tyres with different dimensions, construction of carcass and radius of tread profile curvature (first two in Table 1) are shown in Fig 6-9. The tyre SKYWAY-H 6,15-13 4PR has crosssection of outline similar to a circle. The other tyre GOODYEAR 175/70SR13 4PR has a large radius of tread curvature. The experiments were repeated three 


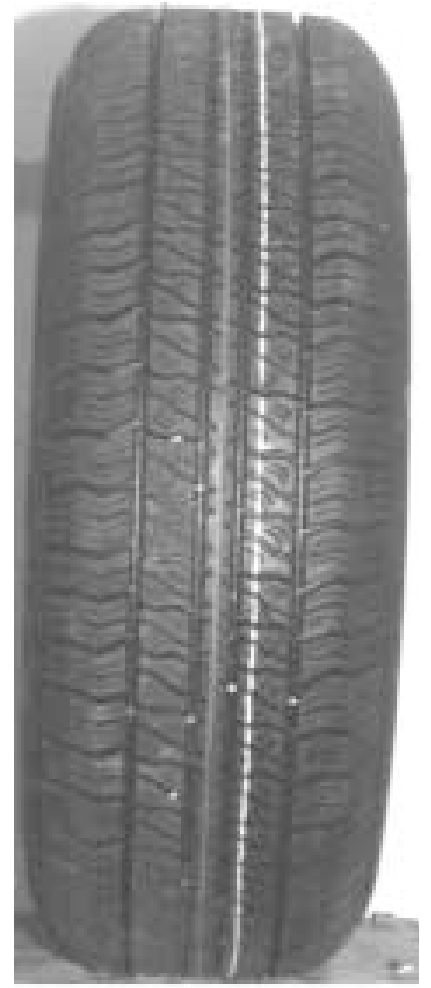

1

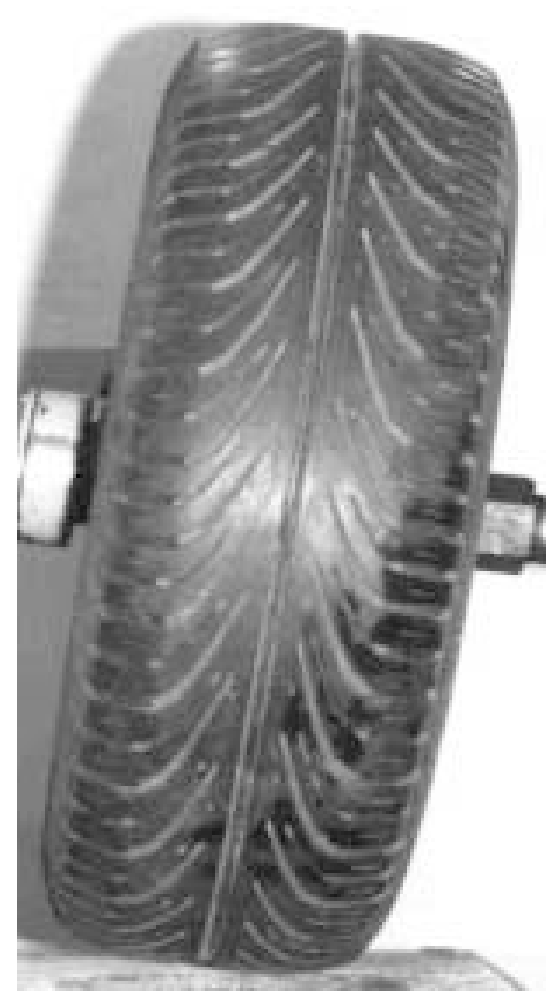

4

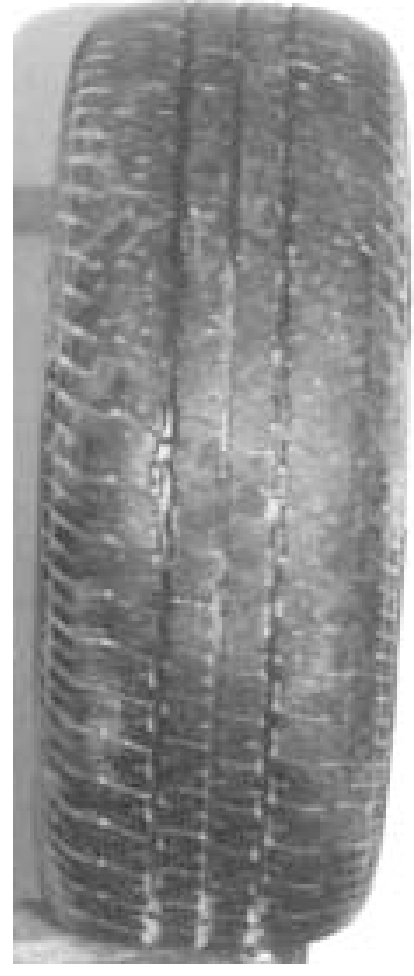

2

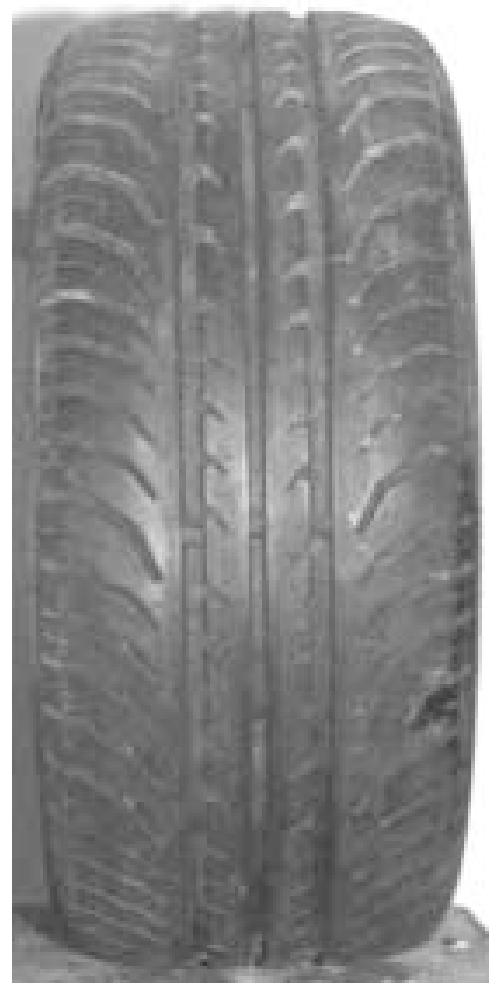

5

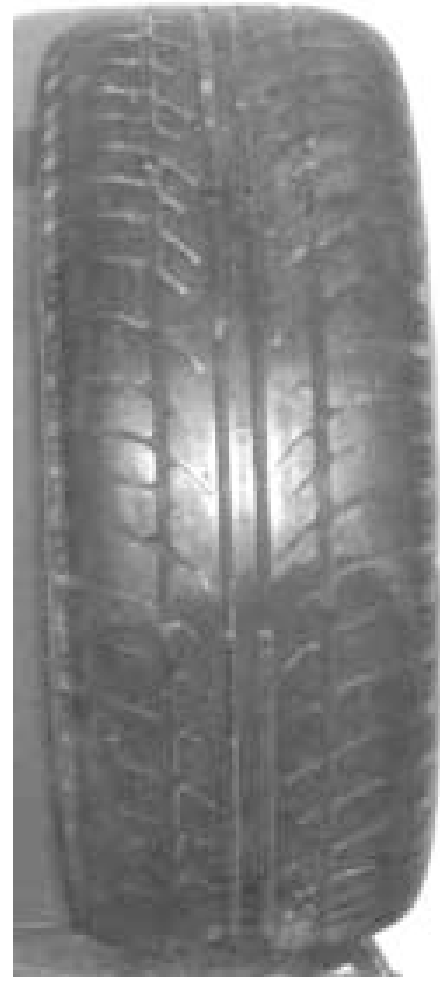

3

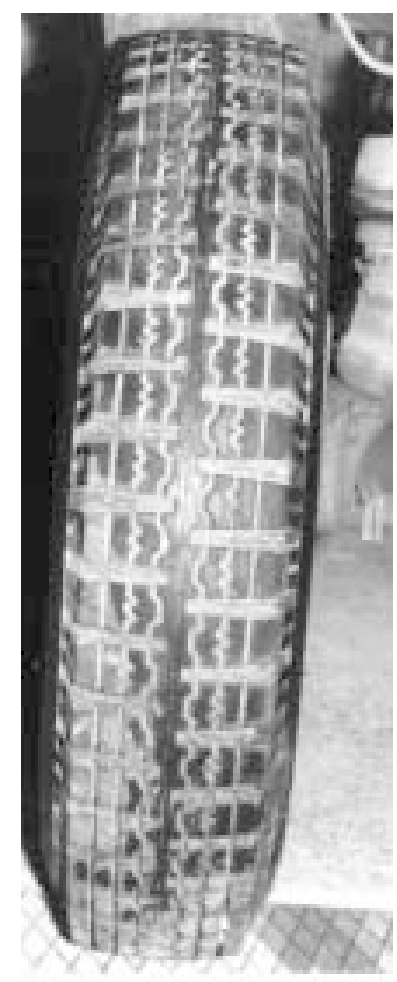

6

Fig 2. Pictures of some of the tested tyres: 1 - Belshina 175/70 R 13 82H; 2 - Goodyear 175/70 SR 13; 3 - Semperit 185/60 R 14 82T; 4 - Nokian 205/65 R15 95H; 5 - Viking 205/50 R15 86V; 6 - Vidlon 6,5-16 


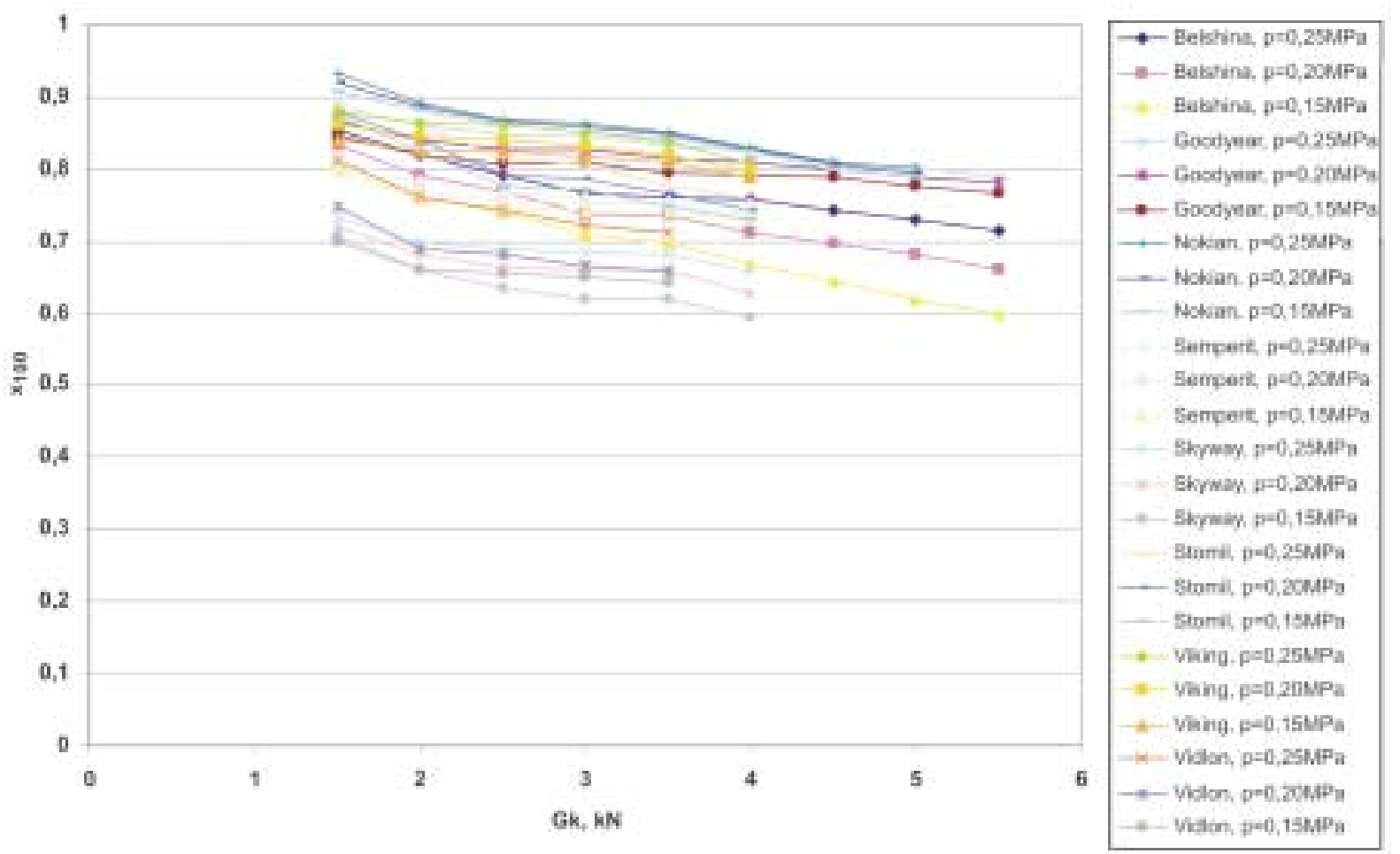

Fig 3. Variation of the sliding grip coefficient of the tested tyres in the longitudinal direction

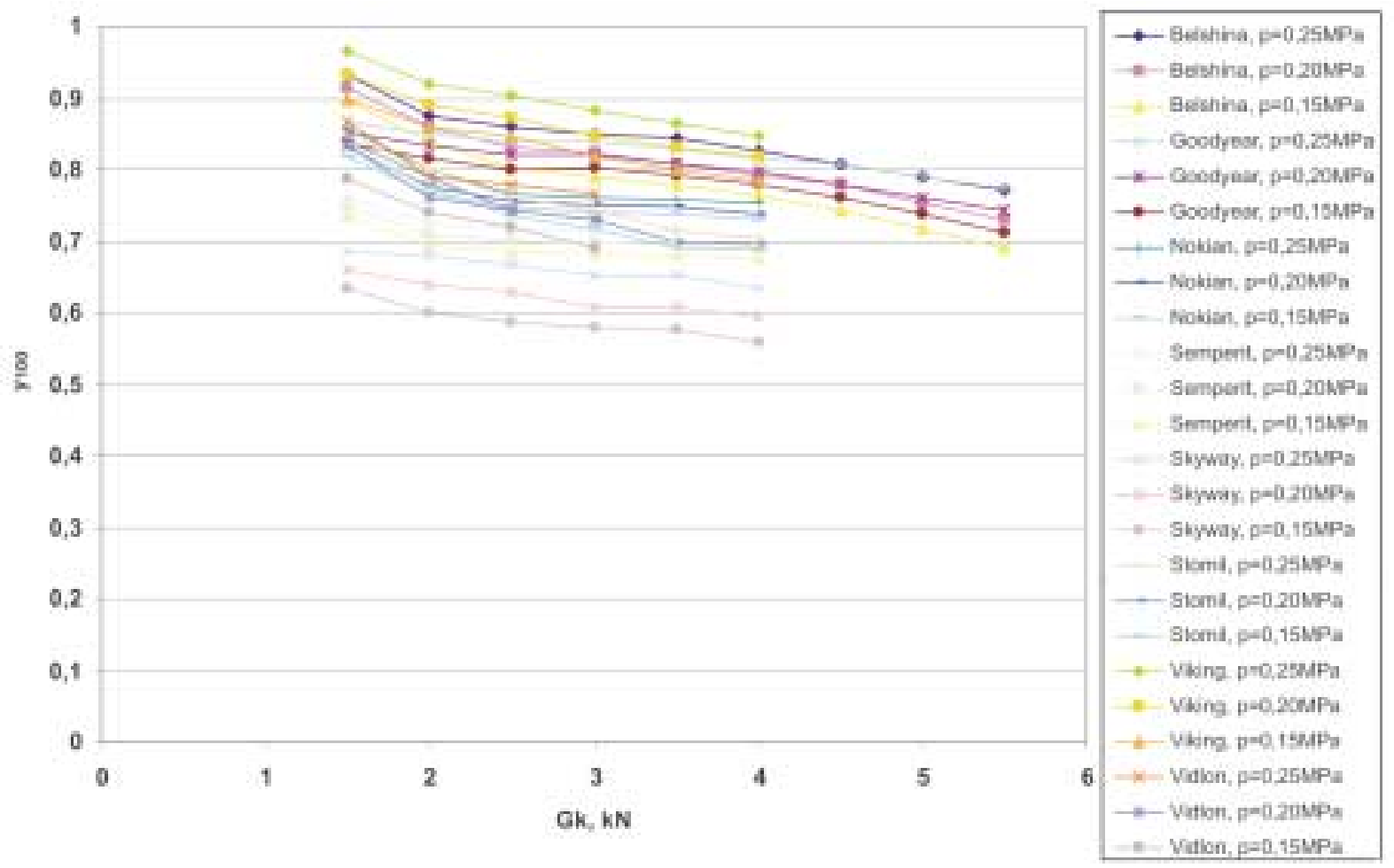

Fig 4. Variation of the sliding grip coefficient of the tested tyres in the lateral direction 


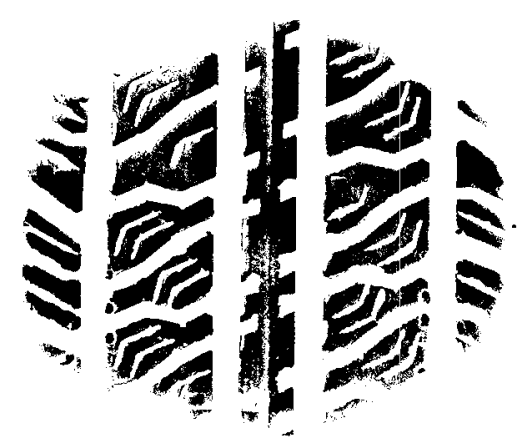

a)

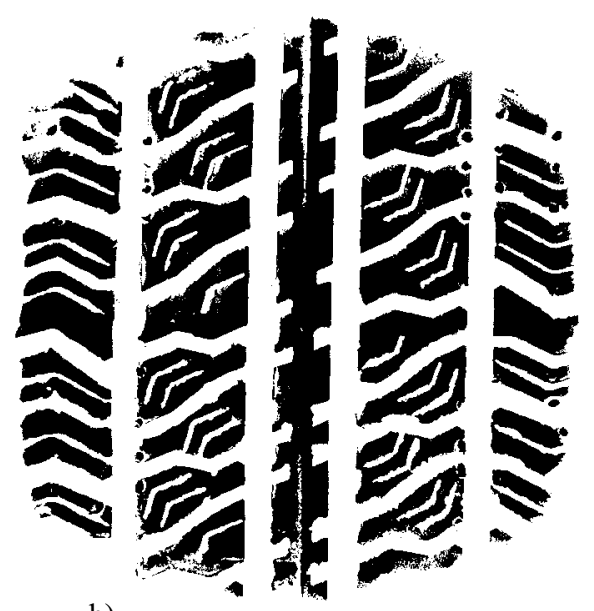

b)

Fig 5. Footprints of the contact patch of the tyre Belshina $175 / 70 \mathrm{R} 1382 \mathrm{H}$ at $0,25 \mathrm{MPa}$ air pressure in the tyre and respective vertical load: $\mathrm{a}-2 \mathrm{kN} ; \mathrm{b}-3,5 \mathrm{kN}$

times using different combination of the values of tyre pressure and vertical load. The wheel camber was changed in an interval from $0^{\circ}$ to $6^{\circ}$ by a step of $2^{\circ}$.

The obtained results show the general regularity for two tyres: the increase of the wheel camber at the same vertical load leads to a significant decrease of the sliding grip coefficients in longitudinal and lateral directions. The causes of this change are: bigger deformation of tyre at the side of wheel inclination, appearance of lateral reaction from the wheel inclination and, on the other hand, the change of the form and the area of the contact patch $[19,20]$. As a result, the stresses in the contact patch, caused only by vertical load, increase, and the tyre loses grip at smaller longitudinal or lateral force.

Except for this general regularity, there are also some others specific for the two tyres.

\section{Tyre SKYWAY-H 6,15-134PR}

At $G_{K}=$ const the increase of wheel camber from $0^{\circ}$ to $6^{\circ}$ causes a decrease of longitudinal sliding grip coefficient $\varphi_{x}$ by about 0,1 and a less decrease of lateral sliding grip coefficient $\varphi_{y}$ - by about 0,075 (Fig 6 and 7).

The curves for different values of wheel camber $\alpha$ are equidistantly disposed. At $G_{K}=1,5 \mathrm{kN}$ the influence of camber $\alpha$ on the coefficient $\varphi_{y}$ is less (the curves are disposed closer). For all values of wheel camber, the curves present a specific zone, in which the coefficients do not change significantly when the vertical load increase. This zone is disposed between 3,0 and 3,5 kN of vertical load. The values of the sliding grip coefficients in two directions are smaller than those for the other tyre.

Tyre GOODYEAR 175/70SR13 4PR

At $G_{K}=$ const the increase of wheel camber from $0^{\circ}$ to $6^{\circ}$ causes a decrease of the longitudinal sliding grip coefficient $\varphi_{x}$ by about 0,15 and a less decrease of lateral sliding grip coefficient $\varphi_{y}$-by about 0,125 (Fig 8 and 9). The curves at $\alpha=0^{\circ}$ and $\alpha=2^{\circ}$ are disposed closer, but the distance between the curves at $2^{\circ}, 4^{\circ}$ and $6^{\circ}$ are about equal. This can be explained by curvature of the tyre tread profile. The other tyre has a big curvature of tread profile and the curves of coefficients are equidistantly disposed, as a result, there is no sudden change of the contact conditions between the tyre and the ground - the contact is disposed in the curve part of the tyre tread profile. The tyre GOODYEAR is bigger in width and the tyre tread profile has a very small curvature. At $2^{\circ}$ it contacts on all width of the tread, and contact conditions are close to that at $0^{\circ}$.

At bigger wheel camber the tyre enters into contact initially by one side of the tyre tread. This side of the tyre profile has a bigger deformation. The other side of the tyre has a smaller load and deformation, or it has no contact with ground at all. This peculiarity can be seen in Fig 10, where footprints of the contact patch of two tyres at the same load conditions and inclination $6^{\circ}$ are shown.

It is obvious that contact patch of the tyre SKYWAY has a similar to the initial form (elliptic form when there is no camber). Contact patch of the tyre GOODYEAR has a quite different form (rectangular form when there is no camber). On the footprint of the tyre SKYWAY in the most loaded and deformed area of the left hand side, a partial slip of the tread elements is clearly seen.

Here also, for all values of wheel camber, the curves present a specific zone, in which the coefficients do not change significantly when the vertical load increases. This zone is disposed between 2,5 and 3,0 kN of vertical load. The values of sliding grip coefficients in two 


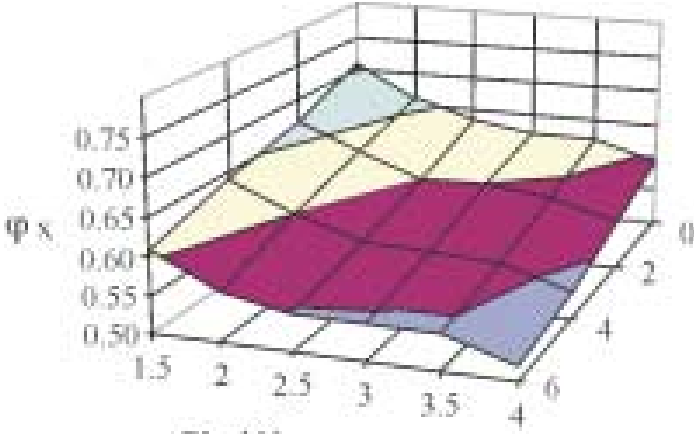

Gk, kN

a)

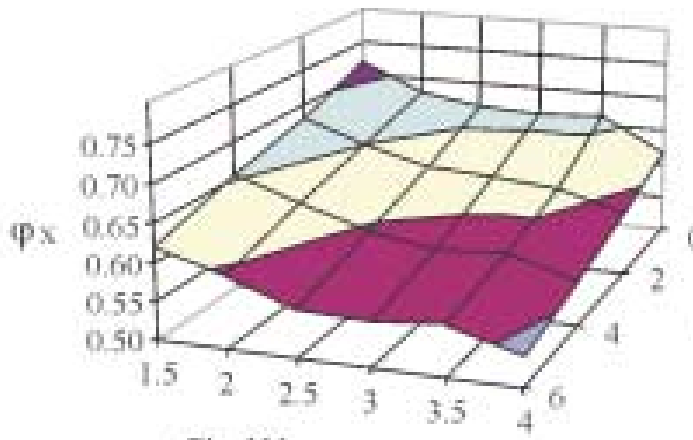

$\mathrm{Gk}, \mathrm{kN}$

b)

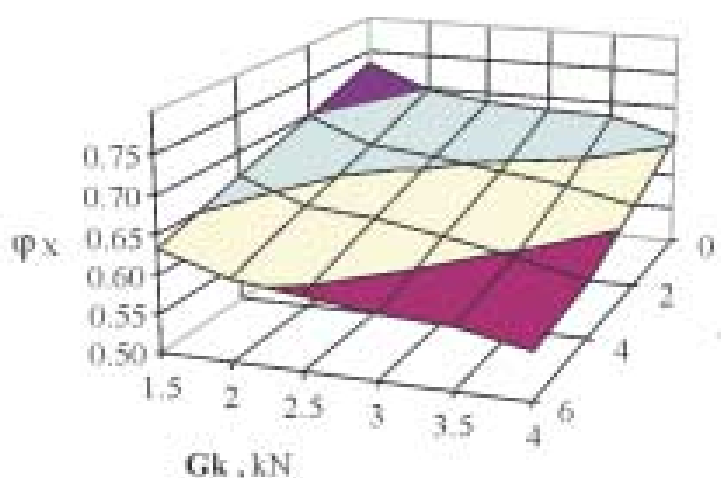

c)

Fig 6. Relationship between the sliding grip coefficient in the longitudinal direction $\varphi_{\mathrm{X}}$, vertical load $G_{\mathrm{K}}$ and wheel camber $\alpha$ at different values of tyre air pressure $p$ for the tyre SKYWAY: $\mathrm{a}-p=0,15 \mathrm{MPa}$; $\mathrm{b}-p=0,20 \mathrm{MPa} ; \mathrm{c}-p=0,25 \mathrm{MPa}$

directions are significantly higher than respective for the other tyre.

However, for making more extensive generalization about the influence of different parameters and construction of the tyre on the sliding grip coefficients, additional investigations have to be done and more experimental data have to be collected.

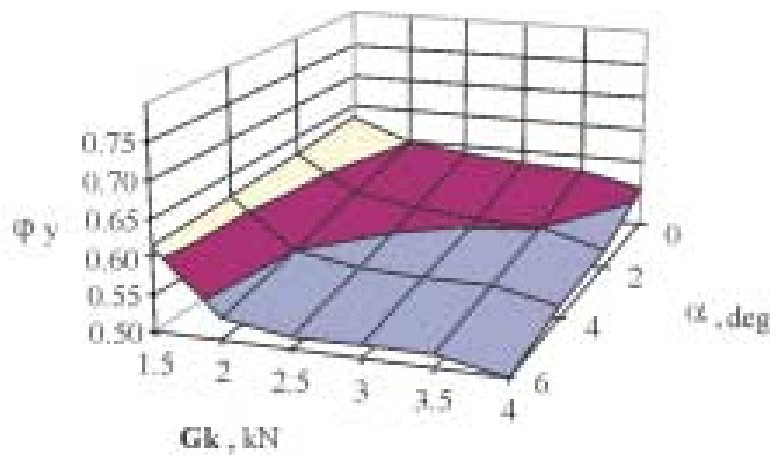

a)

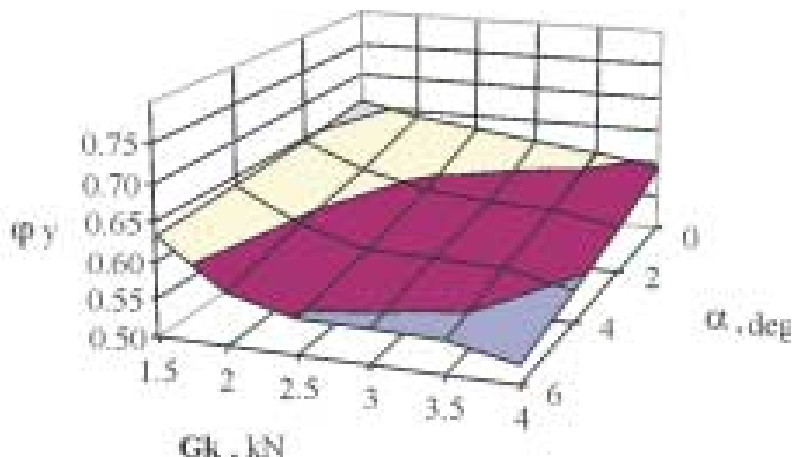

b)

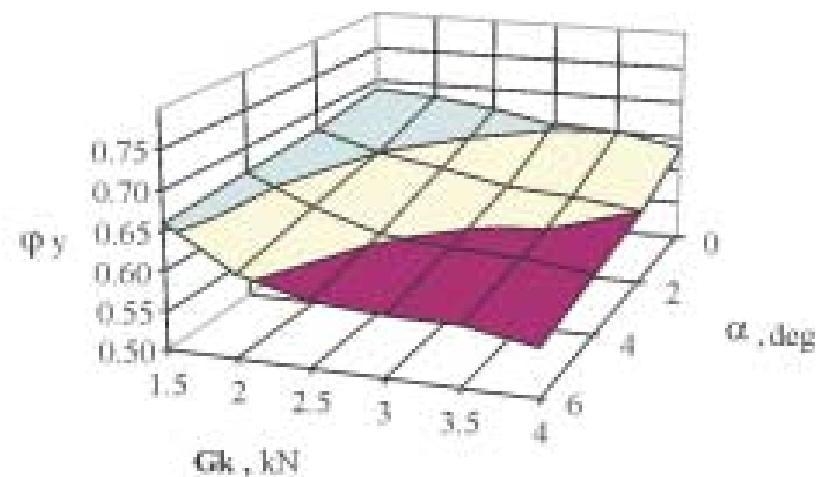

c)

Fig 7. Relationship between the sliding grip coefficient in the lateral direction $\varphi_{\mathrm{Y}}$, vertical load $G_{\mathrm{K}}$ and wheel camber $\alpha$ at different values of tyre air pressure $p$ for the tyre SKYWAY: $\mathrm{a}-p=0,15 \mathrm{MPa}$; $\mathrm{b}-p=0,20 \mathrm{MPa} ; \mathrm{c}-p=0,25 \mathrm{MPa}$

\section{Conclusions}

After analysis of the obtained results the following conclusions can be formulated:

1. The vertical load and the air pressure in the tyre influence significantly the sliding grip coefficients in the longitudinal and the lateral directions at different constructions of tyre, tread design and tyre dimensions. 


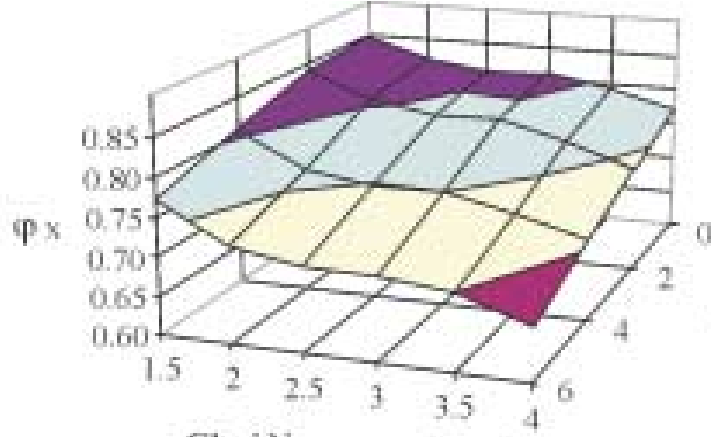

Gk , kN

a)

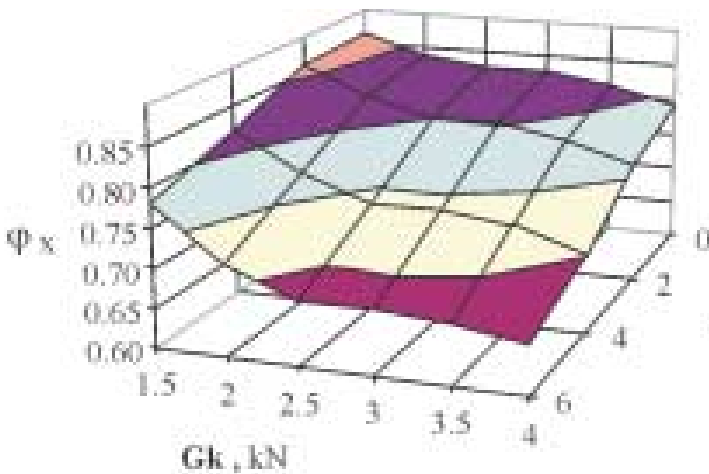

b)

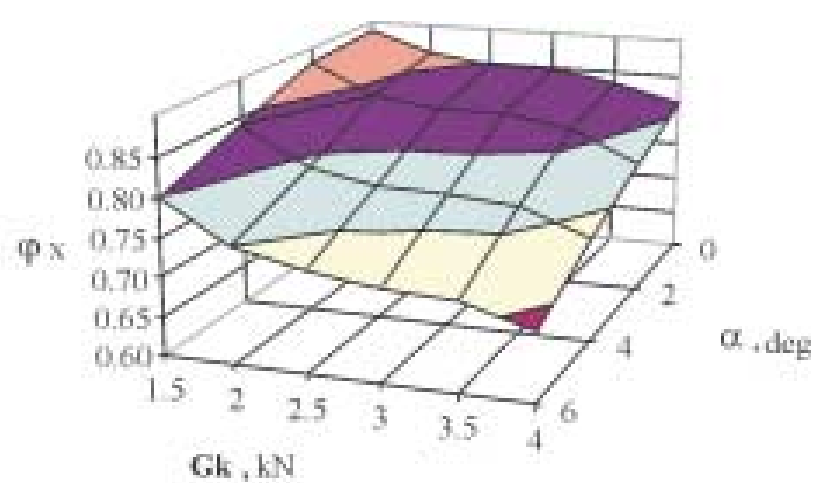

c)

Fig 8. Relationship between the sliding grip coefficient in the longitudinal direction $\varphi_{\mathrm{X}}$, vertical load $G_{\mathrm{K}}$ and wheel camber $\alpha$ at different values of tyre air pressure $p$ for the tyre GOODYEAR: $\mathrm{a}-p=0,15 \mathrm{MPa}$; $\mathrm{b}-p=0,20 \mathrm{MPa} ; \mathrm{c}-p=0,25 \mathrm{MPa}$

Describing the decrease of the sliding grip coefficients with a general model is very difficult, because of different disposition of the specific zone on curves for different tyres, however, this decrease should be taken into account in the more precise investigations.

2. The wheel camber influences significantly the sliding grip coefficients of both tested constructions of the tyres, although they have fundamental constructive

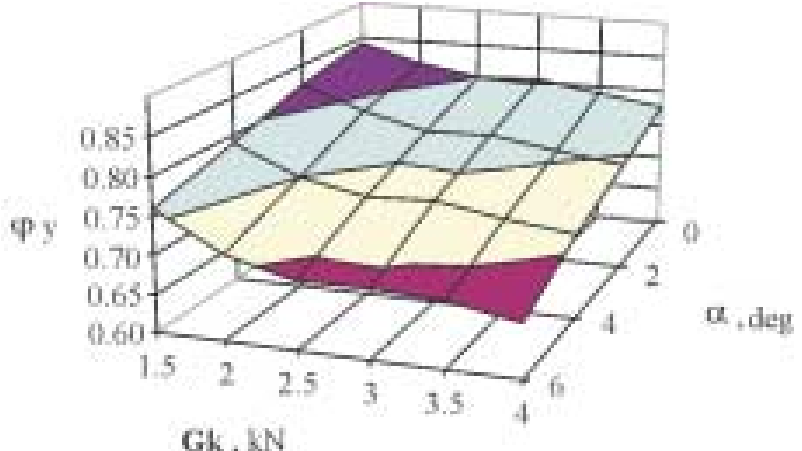

a)

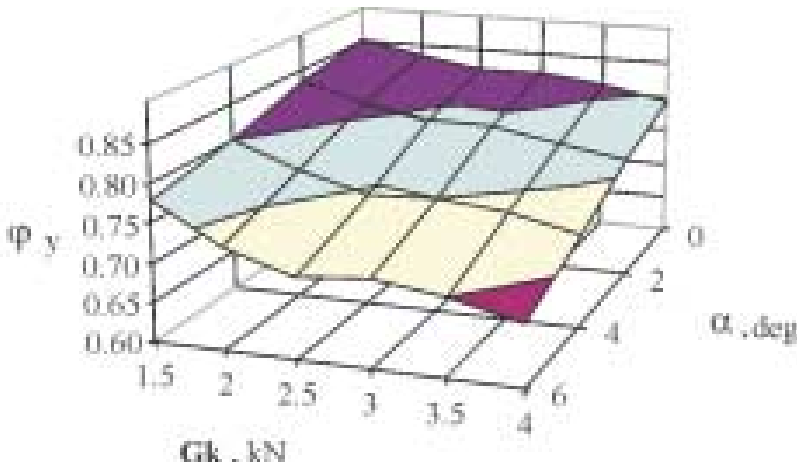

b)

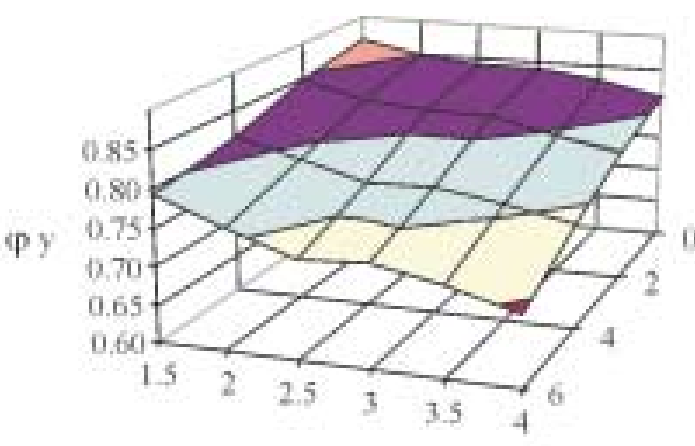

$\alpha$, deg

$\mathbf{G k}, \mathrm{kN}$

c)

Fig 9. Relationship between the sliding grip coefficient in the lateral direction $\varphi_{\mathrm{Y}}$, vertical load $G_{\mathrm{K}}$ and wheel camber $\alpha$ at different values of tyre air pressure $p$ for the tyre GOODYEAR: $\mathrm{a}-p=0,15 \mathrm{MPa}$; $\mathrm{b}-p=0,20 \mathrm{MPa} ; \mathrm{c}-p=0,25 \mathrm{MPa}$

differences. The wheel camber causes a bigger change of the sliding grip coefficients of the wider tyre, which has a small curvature of the tyre tread, because of the more significant change of the contact conditions between the tyre and road surface (form of the contact patch and distribution of the stresses).

3. The character of the sliding grip coefficients change depending on wheel camber is not identical for 


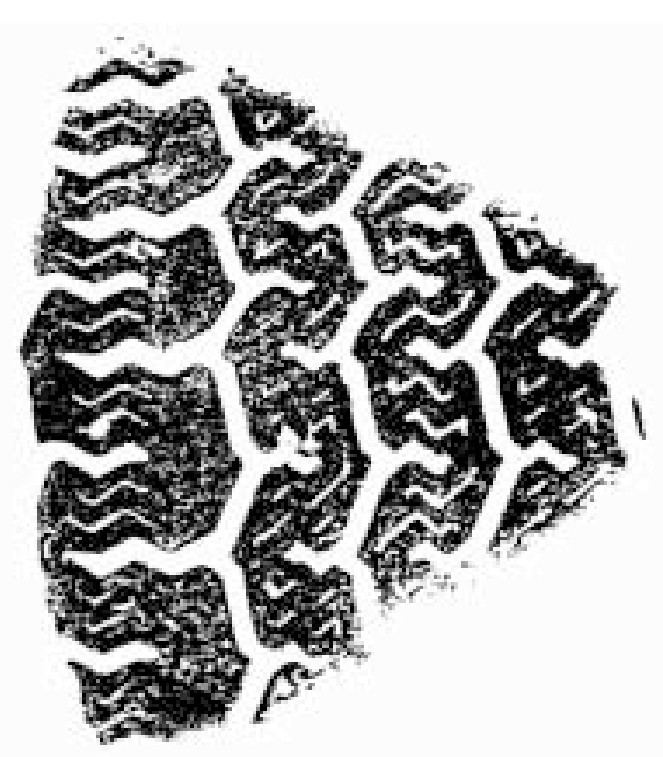

a)

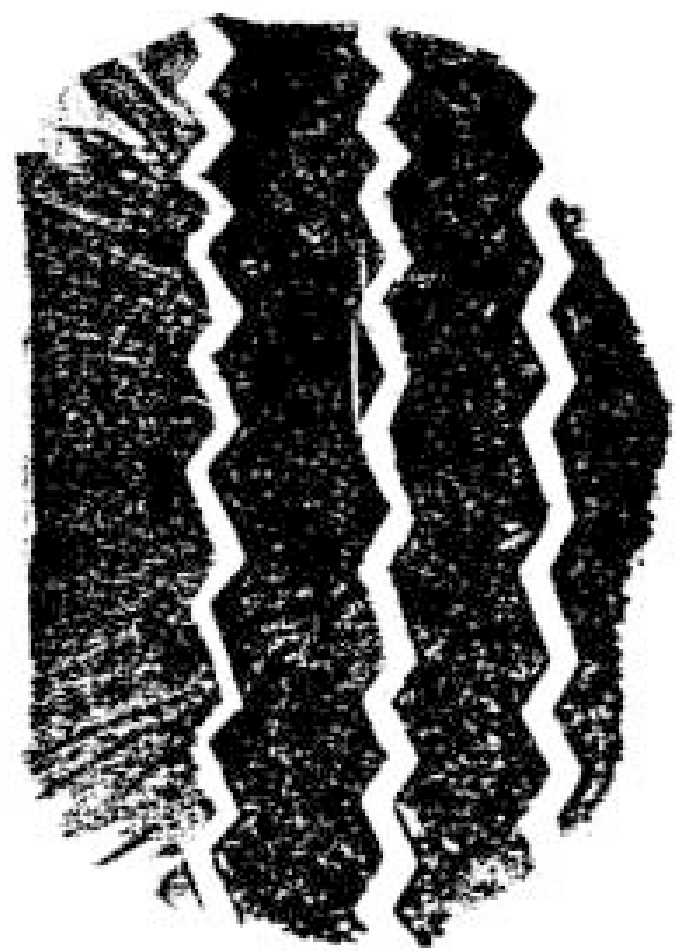

b)

Fig 10. Footprints of contact patch of tyres SKYWAY-H 6,15-13 4PR (a) and GOODYEAR 175/70SR13 4PR (b) at vertical load $G_{K}=3 \mathrm{kN}$ and wheel camber $\alpha=6^{\circ}$

different tyres. For bias-ply tyre, with bigger curvature of tread profile the coefficients decrease proportionally when the inclination of the tyre increases. For radial tyre with less curvature of the tread profile at small values of the wheel camber (to $2^{\circ}$ in this investigation) the influence of the wheel camber is much weaker, but at bigger values it becomes more significant than for the other tyre.

\section{Acknowledgements}

The authors are very grateful to the Fund "Scientific investigations" of Rousse University who have supported this investigation financially.

\section{References}

1. Borovskij, B. E. Automobile transport Safety (Безопасность движения автомобильного транспорта). Leningrad: Lenizdat, 1984 (in Russian).

2. Litvinov, A. S. Steerability and stability of vehicle (Управляемость и устойчивость автомобиля). Moscow: Machinostrojenie, 1971. 416 p. (in Russian).

3. Wong, J. Y. Theory of ground vehicles. John Wiley \& Sons, 1982. 284 p.
4. Knoroz, V. I. Work of vehicle tyre (Работа автомобильной шины). Moscow: Transport, 1976. 238 p. (in Russian).

5. Choi, S.-B.; Bang, J. H.; Cho, M.-S.; Lee, Y.-S. Sliding mode control for anti-lock brake system of passenger vehicles featuring electrorheological valves. Automobile Engineering, Vol 216, No D11, 2002, p. 897-900.

6. Clark, S. K. Mechanics of Pneumatic tires. US Dept of Transportation, National Highway Traffic Safety Administration, 1970.

7. Gilespie, T. Fundamentals of vehicle dynamics. Warrendale, 1992, p. 495.

8. Gipser, M.; Hofer, R.; Lugner, P. Dynamical tire forces response to road unevennesses. In: Proceedings of $2^{\text {nd }}$ Colloquium on Tyre Models for Vehicle Analysis, ed. F. Bohm and H. P. Willumeit. Berlin, 1997, Suppl. Vehicle System Dynamics, 27, 1996.

9. Guo, K. H. The effect of longitudinal force and vertical load distribution on tire slip properties. SAE paper series 945087, 1994.

10. Kageyama, I. On a control of tyre force coefficient for vehicle handling with neural network system. In: Proc. $13^{\text {th }}$ IAVSD Symposium, China, 1993 p. 31-34.

11. Kamnik, R.; Boettiger, F.; Hunt, K. Roll dynamics and lateral load transfer estimation in articulated heavy freight vehicle. Automobile Engineering, Vol 217, No D11, 2003, p. 985. 
12. Mousseau, C. W.; Clark, S. K. An analytical and experimental study of a tire rolling over a stepped obstacle at low velocity. Tire Science and Technology, TSTCA, 1994.

13. Oertel, Ch. On modeling contact and friction calculation of tyre response on unever roads. In: Proceedings of $2^{\text {nd }}$ Colloquium on Tyre Models for Vehicle Analysis, eds. F. Bohm and H. P. Willumeit. Suppl. Vehicle System Dynamics, 27, 1996.

14. Pacejka, H. B. Tyre and vehicle dynamics. SAE, Warrendale, 2002, 622 p.

15. Reimpell, J.; Stoll, H.; Betzler, J. The Automotive Chassis. Butterworth-Heinemann, 2001, p. 444.

16. Shang, J.; Guan, D.; Yam, L. H. Study on tyre dynamics cornering properties using experimental modal parameters. Vehicle System Dynamics, 37.2. 2002.

17. Varat, M. S.; Kerkhoff, J. F.; Husher, S. E.; Armstrong, C. D.; Shuman, K. F. The analisys and determination of tyre-roadway frictional drag. SAE Technical paper series 2003-01-0887, 2003.

18. Zegelaar, P. W. A.; Pacejka, H. B. The in-plane dynamics of tyres on uneven roads. In: Proceedings of $14^{\text {th }}$ IAVSD Symposium on the Dynamics of Vehicles on Roads and Track, ed. L. Segel. Ann Arbor 1995. Suppl. Vehicle System Dynamics, 25, 1996.

19. Ivanov, R. P.; Angelov, B. G. Comparative investigation of pneumatic tyres grip (Сравнително изследване на сцеплението на пневматични гуми). V. Tyrnovo, NT of VVOBU, Vol 48, 1996, p. 55-61 (in Bulgarian).

20. Ivanov, R. P.; Angelov, B. G. Influence of vertical load and tyre pressure on the pneumatic tyre (Влияние на нормалното натоварване и налягането на въздуха върху сцеплението с пътя на пневматична гума). Varna, ISC MOTAUTO’96, Vol II, 1996, p. 47-50 (in Bulgarian).

21. Ivanov, R.; Ilchev, P.; Rousev, R.; Nikolov, V. Laboratory facility for pneumatic tyre testing (Уредба за изпитване на пневматични гуми). Rousse, ISC MOTAUTO'02, Vol II, 2002, p. 101-104 (in Bulgarian).

22. Ivanov, R.; Ivanova, D.; Rousev, R. Neural Network application in tyre cohesion coefficients prediction (Приложение на невронните мрежи за определяне на коефициентите на сцепление на пневматична гума с пътя). Plovdiv, ISC MOTAUTO’04, Vol III, 2004, p. 22-25 (in Bulgarian). 